\title{
THEMES IN BUSINESS AND SOCIETY
}

Editor: Dimitry Anastakis

Themes in Business and Society explores new issues in Canadian and international business history. The series advances Canadian business history in a global context by publishing studies that examine firms, entrepreneurs, consumers, industries, the evolution of capitalism, business-government relations, the role of the state and regulation, and the changing business environment in national and international contexts. Supported by the L.R. Wilson/R.J. Currie Chair in Canadian Business History at the University of Toronto and the Rotman School of Management, Themes in Business and Society provides new perspectives on the central role and tremendous impact of business upon ordinary people, both in Canada and around the world. 


\section{Opportunism and Goodwill}

\section{Canadian Business Expansion in Colombia, 1867-1979}

\section{STEFANO TIJERINA}



(C) University of Toronto Press 2021
Toronto Buffalo London
utorontopress.com
Printed in the U.S.A.

ISBN 978-1-4426-4686-5 (cloth)
ISBN 978-1-4426-6675-7 (EPUB)
ISBN 978-1-4426-6674-0 (PDF)

Themes in Business and Society

\section{Library and Archives Canada Cataloguing in Publication}

Title: Opportunism and goodwill : Canadian business expansion in Colombia, 1867-1979 / Stefano Tijerina.

Names: Tijerina, Stefano, 1969- author.

Description: Series statement: Themes in business and society |

Includes bibliographical references and index.

Identifiers: Canadiana (print) 20200411098 |

Canadiana (ebook) 20200411195 |

ISBN 9781442646865 (hardcover) | ISBN 9781442666757 (EPUB) |

ISBN 9781442666740 (PDF)

Subjects: LCSH: Canada - Foreign economic relations -

Colombia. | LCSH: Colombia - Foreign economic relations - Canada.

Classification: LCC HF1480.15.C65 T55 2021 | DDC 337.710861 - dc23

University of Toronto Press acknowledges the financial assistance to its publishing program of the Canada Council for the Arts and the Ontario Arts Council, an Ontario government agency.

Canada Council for the Arts
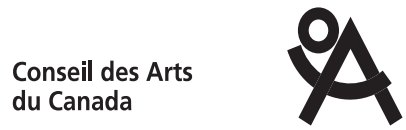

ONTARIO ARTS COUNCIL

CONSEIL DES ARTS DE L'ONTARIO

an Ontario government agency

un organisme du gouvernement de l'Ontario
untario government agency

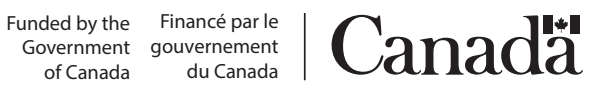

Funded by the Financé par le
Government gouvernement of Canada du Canada

\section{Canadä}

